\title{
SHORT-TERM OBSERVATION ON MARINE DEBRIS AT COASTAL AREAS OF TAKALAR DISTRICT AND MAKASSAR CITY, SOUTH SULAWESI-INDONESIA
}

\author{
Akbar Tahir ${ }^{1 *}$, Shinta Werorilangi ${ }^{1}$, Fajar Mulana Isman ${ }^{1}$, Adi Zulkarnaen ${ }^{1}$, Arniati Massinai ${ }^{1}$, \\ Ahmad Faizal ${ }^{1}$
}

Submitted: June 10, 2018, Accepted: July 23, 2018

\begin{abstract}
Marine debris is defined as material that is solid, persistent, manufactured or processed, and deliberately or notdeliberately left in the marine environment. Marine debris comes in many shapes and forms, ranging in size from microscopic microplastics to large vessels. Marine debris is a big and growing global problem, pose threats to marine life sustainability. Plastic is a major component of marine debris, and single-use packaging accounts for an increasing part of the global marine debris load. Research on marine debris was conducted on coastal areas and Small Island of South Sulawesi destined for local tourism, i.e., Karama beach, Bodia beach and Mandi beach (Galesong, Takalar District), Tanjung Bayang beach, Akkarena beach and Lae-lae island/also known as Bob beach (Makassar City). This research was aimed at identifying marine debris according to its types, size, and mass. Debris was collected in a $25 \times 60 \mathrm{~m}$ transect with direction $30 \mathrm{~m}$ towards land and waters, respectively, with 3 replication transects at every location, whilst collections of debris were conducted during low and high tides. Current (direction and speed) and waves (incoming direction and height) were also measured as supporting parameters. Surrounding sampling location characteristics were also recorded. The result showed that Karama beach is found with highest total marine debris mass in Takalar $(36.44 \mathrm{~kg})$, whilst in Makassar, the Lae-lae island was found to be the highest with debris mass $(43.22 \mathrm{~kg})$. Plastic was predominant debris at all sampling locations with percentages of $62.7-86.6 \%$. Lastly, the predominant size was macro-debris $(25-100 \mathrm{~cm})$.
\end{abstract}

Keywords: Marine debris, plastics, macro-debris, South Sulawesi.

\section{INTRODUCTION}

The accumulation of litter at sea and along coastlines worldwide have raised many open questions concerning the amount, distribution and fate of marine litter and potential implications for marine wildlife and humans have triggered public awareness, stimulated scientific research and initiated political action to tackle this environmental problem (UNEP, 2009). The environmental and other problems arising from indiscriminate disposal of plastics and other persistent synthetic materials (marine debris) into the global oceans and seas are chronic rather than acute and are international problems (Thompson et al. 2009). Marine debris is defined as material that is solid, persistent, manufactured or processed, and deliberately or notdeliberately left in the marine environment. Furthermore, marine debris comes in many shapes and forms, ranging in size from microscopic microplastics to large vessels.

Marine debris is now widely recognized as a major threat to marine biodiversity (CBD, 2012), marine debris research represents a rapidly evolving field, although action to prevent marine debris appears to be developing relatively slow. Studies have documented at least 690 species that have been ingested entangled

Corresponding author:

Akbar Tahir ${ }^{1 *}$

Email: akbar_tahir@mar-sci.unhas.ac.id

${ }^{1}$ Department of Marine Science, University of Hasanuddin, in marine debris, with at least $17 \%$ of species affected listed as threatened or near-threatened (Gall \& Thompson, 2015).

Marine debris has become one of the most widespread pollution problems in the world's oceans and waterways today. Therefore, marine debris monitoring on shorelines has become an increasingly common undertaking for academic, government, and environmental organizations. Shoreline surveys are usually more accessible, inexpensive, and straight forward. Often the highest debris concentrations are found on shorelines, which facilitates data analysis and trend assessment. Jambeck et al. (2015) stated that increasing numbers of marine debris in the coastal area is mostly generated by anthropogenic activities. In the view of prominence debris in the marine environment, observations on types, sizes, and masses of marine debris were carried out in three spots, respectively, at Makassar City and Takalar District shorelines.

\section{MATERIAL AND METHODS}

Investigations of marine debris were carried out between August-October 2016 in Tanjung Bayang and Akkarena beaches and Lae-lae Island (Makassar City), also in Karama, Bodia and Mandi Beaches (Takalar District) (Fig. 1). At each location, three-line transects $(25 \times 60 \mathrm{~m})$ was used to census debris occurrence during high and low tides (NOAA, 2013; Fig. 2). In each transect, debris was collected and identified, measured, and weighed. Positions of sampling 
locations were recorded using GPS. Debris types and sizes identification were conducted according to Lippiatt et al. (2013), in which marine debris was divided into 5 categories according to its size, i.e. mega-debris (> $1 \mathrm{~m})$, macro-debris $(2.5-100 \mathrm{~cm})$, mesodebris $(>5 \mathrm{~mm}-<2.5 \mathrm{~cm})$, micro-debris $(0.33-5 \mathrm{~mm})$ and nano-debris $(<330 \mu \mathrm{m})$.

Current speed was measured using 'current-kites' four times at each sampling location, i.e., towards low-tide, at low-tide, at rising-tide, and high-tide, using spannedropes and compass (Rasyid et al., in Bahar, 2015). Meanwhile, measurement of waves height was conducted 51 times in every 2 hours for 12 hours (06.00 - 18.00) at scale-rod which observe the peak and decline of waves using a stop-watch. Incoming wave directions were observed with the use of an aimed compass.

One-way ANOVA analysis was performed three times, i.e., first, to detect differences in debris mass among locations; secondly, to see differences in the average total numbers of debris among locations; and thirdly, to compare differences in types of debris. Pair t-test was also performed to compare debris masses and sizes at different period of tides.

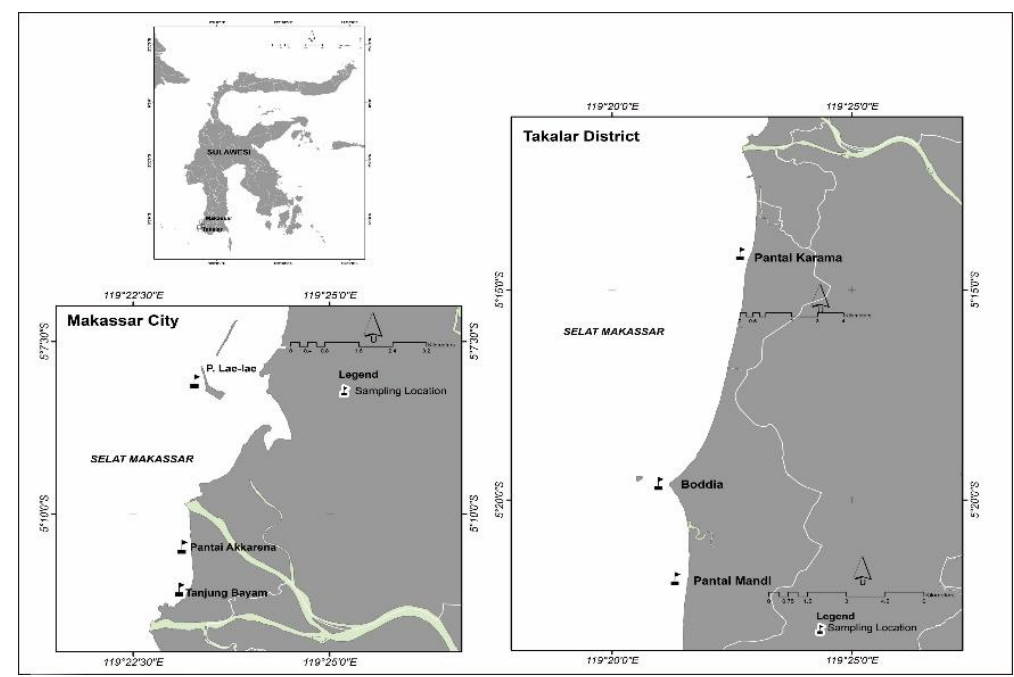

Figure 1. Sampling locations at Makassar City and Takalar District.

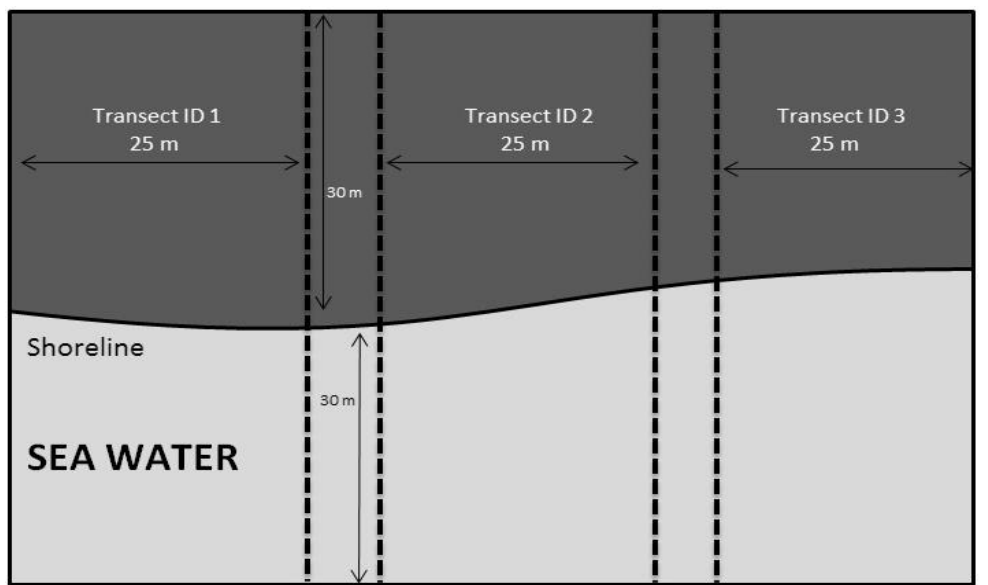

Figure 2. Lay Out of Marine Debris Observation Plots at Each location (Based on NOAA, 2013)

\section{RESULTS AND DISCUSSION}

Three locations in Makassar City were relatively popular as tourist destination areas. First, Tanjung Bayang beach (about $3 \mathrm{~km}$ from the city center) with a coastal area spanned around $1,500 \mathrm{~m}$, with around 6,000 people/month domestic and foreign visitors and is run by local community and government. Second, Akkarena beach is operated by a private company (PT.
Gowa Makassar Tourism Development, Tbk) with a total area around $12 \mathrm{ha}$, and a coast line around $850 \mathrm{~m}$, and it is about $2 \mathrm{~km}$ from the city center. This area has crowded 47,872 visitors (domestic and foreign) permonth. Third, Bob beach was located at the northern part of Lae-lae island with a coast line around $200 \mathrm{~m}$ and about $1 \mathrm{nM}$ from Makassar City, with regular 
visitors around 300 people/month. Locations in Takalar District were very different compared to Makassar, although at all seashore areas pes-caprae (crawling) vegetation was found to be predominant. Karama beach is the nearest location from Makassar City $( \pm 7 \mathrm{~km})$ with a coast line around $220 \mathrm{~m}$. The dominant activity is high-intensity fishing. Bodia beach is in Galesong sub-district with a coast line around $190 \mathrm{~m}$ and dominated by the sandy substrate. The distance of Galesong sub-district from Makassar is around 18.7 $\mathrm{km}$, and dominant activities are fishing (medium intensity) and local sea transportation. Mandi beach is the farthest of all beaches from Makassar City $( \pm 26$ $\mathrm{km}$ ) and is dominated by fishing activity (low intensity) with a was around $160 \mathrm{~m}$.

Based on debris types collected at all sampling locations (Makassar and Takalar; Fig. 3) significant difference $(p<0.05: n=6)$ was observed. The post hoc test also showed a significant difference between plastics and other debris $(\mathrm{p}<0.05: \mathrm{n}=6)$ in all locations that supported by previous findings at Pantai Indah Kapuk Jakarta where plastics accounted for $77.7 \%$ (Hastuti, 2014), and also confirmed by NOAA results (2016) that stated the majority of plastics in marine debris surveys.
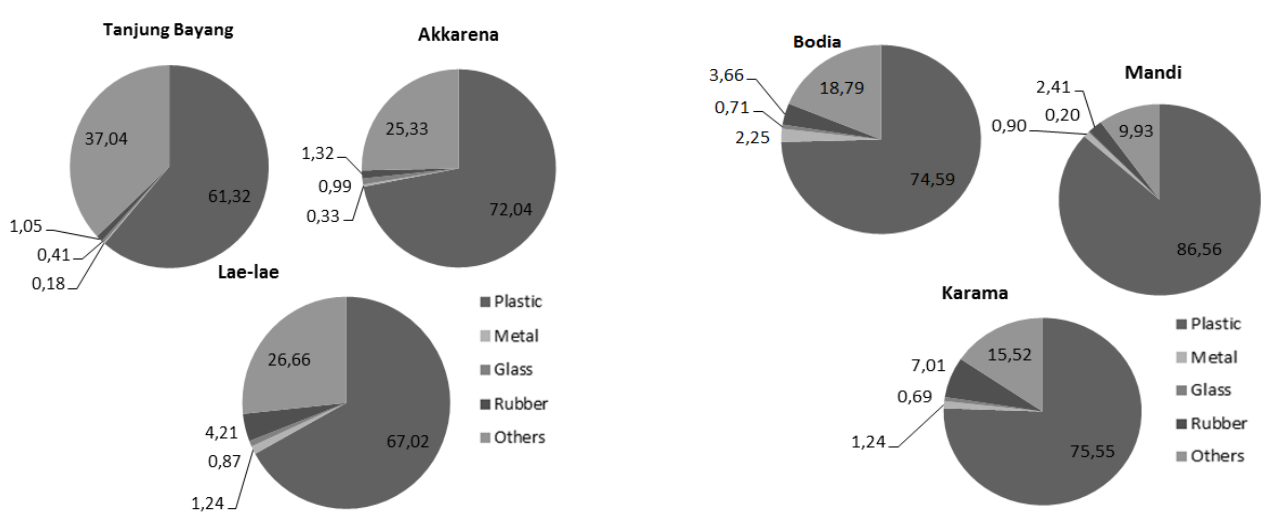

Figure 3. Distribution of Debris Types in All Sampling Location at Different Period of Tides.

For the whole sizes of marine debris, macro-debris was the most repeatedly found at all sampling locations, both in Makassar City and Takalar District.
The abundance of macro-debris was found to be significantly different $(\mathrm{p}<0.05: \mathrm{n}=6)$ compared to other debris' sizes at all locations (Fig. 4).

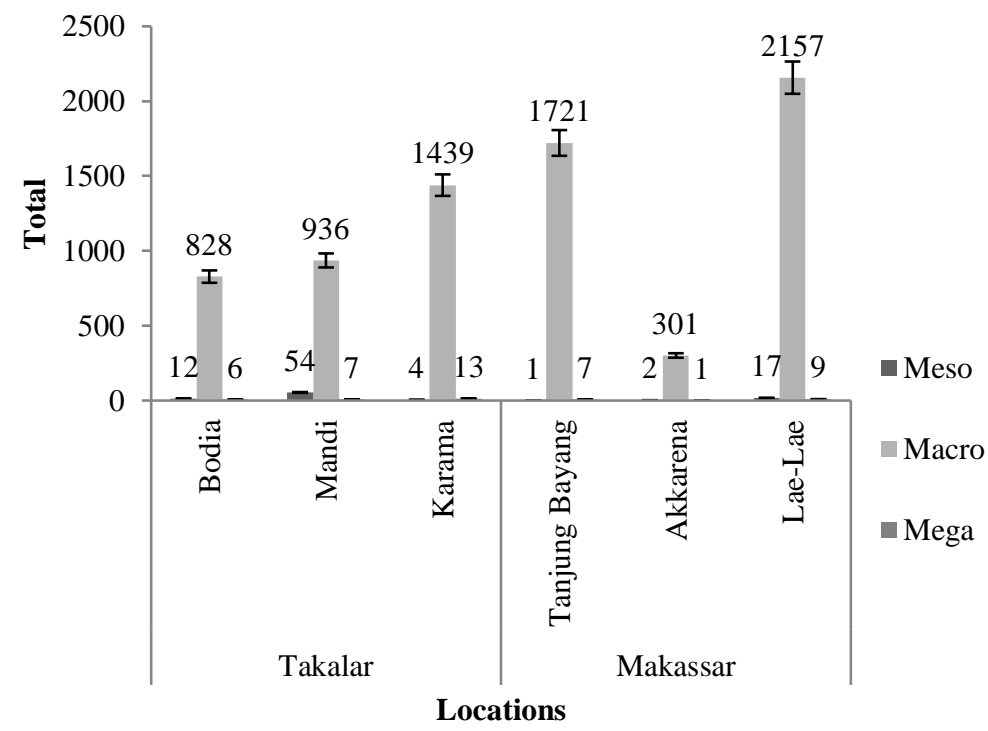

Figure. 4. Average Distribution of Marine Debris Based on Their Size at All Sampling Locations ( $\mathrm{n}=6$ ). 
The most frequent discovered size of debris was macro debris $(2.5-100 \mathrm{~cm})$ in all sampling locations, both at low and high tides $(\mathrm{p}<0.05$; Table 1$)$. In all sampling locations of Makassar City, all debris sizes are mostly found during high tide. However, there was no significant difference on debris size between the tide periods, except with macro debris in Tanjung Bayang beach following pair t-test $(\mathrm{p}<0.05)$. Meanwhile, using pair t-test to compare the occurrence of debris on both tide periods showed no difference in total numbers of debris, with the exception for meso debris in Bodia beach and macro debris in Karama beach of Takalar District $(\mathrm{p}<0.05)$. The abundance of macro debris in Karama during low tide period is presumably due to the previous accumulation of plastic debris and temporarily occurred debris during the high tide period while high numbers of meso debris at Bodia beach was probably due to irregular numbers of meso debris observed in all plots resulting in a significant difference.

Table 1. Variation in Numbers of Debris Sizes collected at Different Tide Periods.

\begin{tabular}{llllllll}
\hline \multirow{2}{*}{$\begin{array}{l}\text { Periods of } \\
\text { Tide }\end{array}$} & Types & Takalar & \multicolumn{5}{c}{ Makassar } \\
\cline { 3 - 8 } & Bodia & Mandi & Karama & Tanjung Bayang & Akkarena & Lae-Lae \\
\hline \multirow{3}{*}{ Low } & Meso & 11 & 51 & 3 & 0 & 0 & 0 \\
& Macro & 726 & 834 & 1202 & 133 & 83 & 177 \\
& Mega & 5 & 7 & 11 & 1 & 1 & 0 \\
\hline \multirow{3}{*}{ High } & Meso & 1 & 3 & 1 & 1 & 2 & 17 \\
& Macro & 102 & 102 & 237 & 1588 & 218 & 1980 \\
& Mega & 1 & 0 & 2 & 6 & 0 & 9 \\
\multirow{3}{*}{ Total } & Meso & 12 & 54 & 4 & 1 & 2 & 17 \\
& Macro & 828 & 936 & 1439 & 1721 & 301 & 2157
\end{tabular}

Debris masses between high and low tides were significantly different $(\mathrm{p}<0.05: \mathrm{n}=6)$ for both Makassar and Takalar (Table 2), except at the Akkarena beach. There is a routine early morning clean up the action and adequate availability of waste containers in Akkarena beach provided by the management, and being as a recreational area, this area was also equipped with seawall construction in front side of the beach, hence reducing water flow/current that might contain debris.

Table 2. Total Mass of Marine Debris at All Sampling Locations.

\begin{tabular}{|c|c|c|c|c|}
\hline City/District & Location & High Tide & Low Tide & $\begin{array}{l}\text { Total } \\
(\mathrm{Kg})\end{array}$ \\
\hline \multirow{3}{*}{ Takalar } & Karama & 7.22 & 29.22 & 36.44 \\
\hline & Bodia & 4.41 & 22 & 26.41 \\
\hline & Mandi & 2.48 & 14.14 & 16.62 \\
\hline \multirow{3}{*}{ Makassar } & $\begin{array}{l}\text { Tanjung } \\
\text { Bayang }\end{array}$ & 20.69 & 6.81 & 27.5 \\
\hline & Akkarena & 9.69 & 3.72 & 13.41 \\
\hline & Lae-lae & 36.45 & 6.77 & 43.22 \\
\hline
\end{tabular}

Differences in marine debris number discovered between Makassar City and Takalar District were affected by the time of observation. In Makassar, collection of marine debris was initiated during the high tide period (from 06.00 on-ward), while in Takalar marine debris observation was started during the low tide period ( 06.00 on-ward) within observation periods of September-October 2016. Indeed, differences in tide periods will imply the pattern and speed of current which can significantly affect the distribution of marine debris in both areas of observation (Sakka, 2010; Opfer et al., 2012).

Typically, waves' height was increased concurrence with the happening of high tide (Table 3; Fig.5). In both Makassar and Takalar, wave directions were from west or southwest during the period of high tide, in other 
words straightforward direction to the seashore. This would strongly affect the shoreline parallel flow current, which will be failed to drift debris to another area, and remained in the coastline. In all observation locations, current directions were northerly during the low tide period. The highest value of significant waves height was observed at Bodia beach (Fig. 5) compared to other locations. Significant wave height will agitate waters, hence having the potential to remove marine debris both in water column and bottom to other places (Brunner, 2014; see Table 1). However, this condition is incomparable with Akkarena beach, which completed with breakwater/seawall construction.

Table 3. Current Speed and Direction in Two Periods of Tide.

\begin{tabular}{llllll}
\hline \multirow{2}{*}{ City/District } & Location & $\begin{array}{l}\text { High Tide } \\
\text { Speed } \\
\text { V=m/sec }\end{array}$ & $\begin{array}{l}\text { Incoming } \\
\text { Direction }\end{array}$ & $\begin{array}{l}\text { Speed } \\
\mathrm{V}=\mathrm{m} / \mathrm{sec}\end{array}$ & Direction \\
\hline \multirow{3}{*}{ Takalar } & Karama & 0.14 & South & 0.08 & North \\
& Bodia & 0.26 & South & 0.07 & North \\
& Mandi & 0.04 & South & 0.02 & North \\
\hline \multirow{3}{*}{ Makassar } & Tanjung & 0.02 & South & 0.07 & North \\
& Bayang & 0.01 & Irregular & 0.02 & Irregular \\
& Akkarena & 0.04 & South-west & 0.07 & North \\
\hline
\end{tabular}

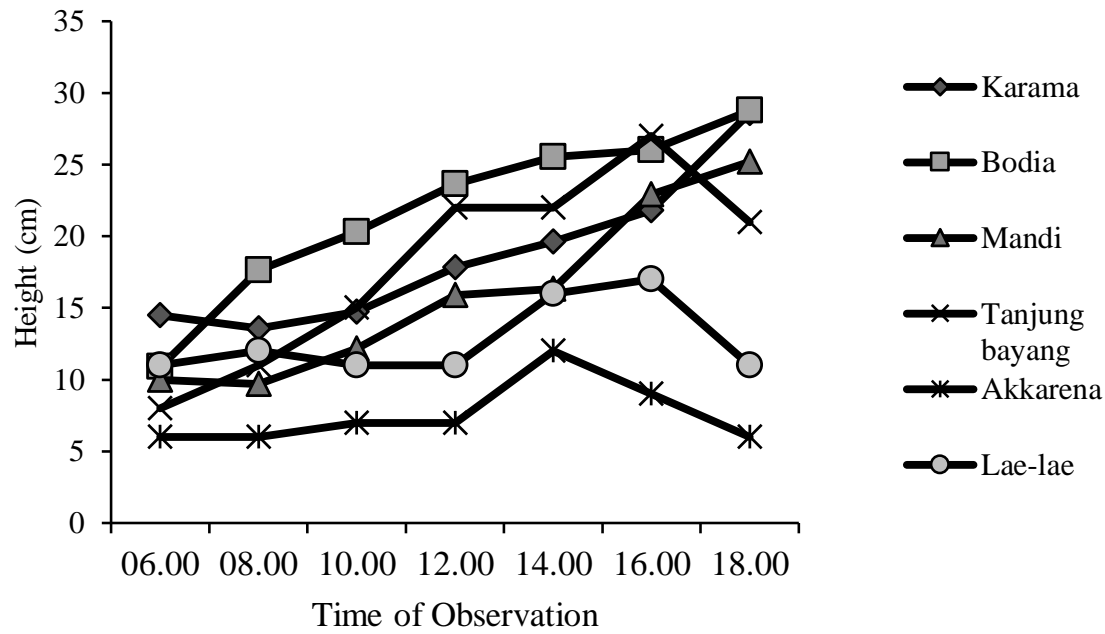

Figure 5. Fluctuations in Wave Heights at all Sampling Locations.

\section{CONCLUSION}

In conclusion, oceanographic parameters such as current and waves are playing important roles in the distribution and concentration of marine debris at

certain shoreline location. Moreover, coastal area management may also significantly affect the volume or quantity of debris as seen in Akkarena beach

\section{REFERENCES}

Bahar, A., 2015. Pedoman Survei Laut. Masagena Press. Makassar. 87 p.

Brunner, K. 2014. Effect of Wind and Wave-Driven Mixing on Subsurface Plastic Marine Debris
Concentration. Thesis. University of Delaware. $132 \mathrm{p}$.

CBD, 2012. Secretariat of the Convention on Biological Diversity and the Scientific and Technical Advisory Panel-GEF, 2012. Impacts of Marine Debris on Biodiversity: Current Status and Potential Solutions, Montreal, Technical Series No. 67, 61 p.

Gall, S. \& Thompson, R., 2015. The Impact of Debris on Marine Life. Marine Pollution Bulletin, 92 (1-2): 170-179.

Hastuti A.R. 2014. Distribusi Spasial Sampah Laut di Ekosistem Mangrove Pantai Indah Kapuk Jakarta. Departemen Manajemen Sumber Daya Perairan. IPB. Bogor. 67 p. 
Jambeck R., J., Roland G., Chris W., Theodore R., S., Miriam P., Anthony A., Ramani N., and Kara L. 2015. Plastic Waste Inputs from Land into the Ocean. Science 347: 768-771.

Lippiatt, S., Opfer, S., and Arthur, C., 2013. Marine Debris and Monitoring Assesment. NOAA. 88 p.
NOAA [National Oceanic and Atmospheric Administration]. 2013. Programmatic Environmental Assessment (PEA) for the NOAA Marine Debris Program (MDP). Maryland (US): NOAA. 168 p.

NOAA. 2016. Marine Debris Impacts on Coastal and Benthic Habitats. NOAA Marine Debris Habitat Report. 31 p. 